\title{
Role of Cdx-2 in insulin and proglucagon gene expression: a study using the RIN-1056A cell line with an inducible gene expression system
}

\author{
Yi Zhao ${ }^{1,5}$, Tao Liu ${ }^{1,5}$, Nina Zhang ${ }^{2,5}$, Fenghua $\mathrm{Yi}^{1,5}$, \\ Qinghua Wang ${ }^{2,5}$, Ivan George Fantus ${ }^{1-5}$ and Tianru Jin ${ }^{1,3-5}$ \\ ${ }^{1}$ Division of Cell and Molecular Biology, Toronto General Research Institute, University Health Network, University of Toronto, Ontario, Canada \\ Departments of ${ }^{2}$ Physiology, ${ }^{3}$ Medicine and ${ }^{4}$ Laboratory Medicine and Pathobiology, University of Toronto, Toronto, Ontario, Canada \\ ${ }^{5}$ Banting and Best Diabetes Center, Faculty of Medicine, University of Toronto, Ontario, Canada \\ (Requests for offprints should be addressed to T Jin, Room 421, CBS Site, Toronto General Research Institute, University Health Network, \\ University of Toronto, 67 College St, Toronto, Ontario M5 G 2 M1, Canada; Email: tianru.jin@utoronto.ca)
}

\begin{abstract}
Although the homeobox gene $\mathrm{Cdx}-2$ was initially isolated from the pancreatic $\beta$ cell line HIT-T15, no examination of its role in regulating endogenous insulin gene expression has been reported. To explore further the role of Cdx-2 in regulating both insulin and proglucagon gene expression, we established an ecdysone-inducible $\mathrm{Cdx}-2$ expression system. This report describes a study using the rat insulinoma cell line RIN-1056A, which abundantly expresses both insulin and proglucagon (glu), and relatively high amounts of endogenous Cdx-2. Following the introduction of the inducible $\mathrm{Cdx}-2$ expression system into this cell line and the antibiotic selection procedure, we obtained novel cell lines that displayed dramatically reduced expression of endogenous $\mathrm{Cdx}-2$, in the absence of the inducer. These novel cell lines did not express detectable amounts of glu mRNA or the glucagon hormone, while their
\end{abstract}

insulin expression was not substantially affected. In the presence of the inducer, however, transfected $\mathrm{Cdx}-2$ expression was dramatically increased, accompanied by stimulation of endogenous Cdx-2 expression. More importantly, activated Cdx-2 expression was accompanied by elevated insulin mRNA expression, and insulin synthesis. Cdx-2 bound to the insulin gene promoter enhancer elements, and stimulated the expression of a luciferase reporter gene driven by these enhancer elements. Furthermore, $\mathrm{Cdx}-2$ and insulin gene expressions in the wild-type RIN-1056A cells were stimulated by forskolin treatment, and forskolin-mediated activation on insulin gene expression was attenuated in the absence of $\mathrm{Cdx}-2$. We suggest that $\mathrm{Cdx}-2$ may mediate the second messenger cAMP in regulating insulin gene transcription.

Journal of Endocrinology (2005) 186, 179-192

\section{Introduction}

Pancreatic islets consist of three major types of endocrine cells, synthesizing three different peptide hormones that are important in blood glucose homeostasis. These include glucagon-producing $\alpha$ cells, insulin-producing $\beta$ cells and somatostatin-producing $\delta$ cells. Many cell type specific transcription factors, including a number of homeodomain (HD) proteins, were found to regulate the genesis of these hormone-producing cells, as well as the expression of correspondent peptide hormone-encoding genes. Some transcription factors have been found to regulate more than one hormone-encoding gene. For example, $\mathrm{Pdx}-1$ is expressed in both $\beta$ and $\delta$ cells in pancreatic islets and in duodenal cells, and regulates the expression of both insulin and somatostatin genes (Leonard et al. 1993, Ohlsson et al. 1993, Miller et al. 1994, Lu et al. 1996). Pax-6 is probably involved in regulating the expression of genes that encode insulin, glucagon and somatostatin respectively (Sander et al. 1997, St-Onge et al. 1997, Andersen et al. 1999, Hussain \& Habener 1999).

The caudal homeobox gene $\mathrm{Cdx}-2$ was demonstrated to be a transactivator for the proglucagon gene (glu) (Jin \& Drucker 1996, Laser et al. 1996, Jin et al. 1997, Hussain \& Habener 1999). Cdx-2 binds to the GC subelement of the G1 enhancer in the rat glu promoter, and stimulates its activity (Jin \& Drucker 1996). Stably overexpressing $\mathrm{Cdx}-2$ was also found to enhance endogenous glu mRNA expression in the pancreatic $\alpha$ cell line, InR1-G9 (Jin et al. 1997). The hamster Cdx-2 cDNA (Cdx-3), however, was first isolated from a pancreatic $\beta$ cell line HIT-T15 by German et al. in 1992. Although German et al. (1992) have demonstrated the activation of a fusion promoter containing the FLAT element of the rat insulin I gene promoter by $\mathrm{Cdx}-2$ cDNA transfection, no studies have been conducted examining the role of $\mathrm{Cdx}-2$ in regulating 
endogenous insulin mRNA expression and insulin synthesis.

To clarify the role of Cdx-2 in regulating both glu and insulin gene expression, and the genesis of the hormoneproducing cells, we established an ecdysone-inducible $\mathrm{Cdx}-2$ gene expression system. In this report, we show the effect of $\mathrm{Cdx}-2$ overexpression on insulin gene expression and insulin synthesis in the rat insulinoma cell line RIN-1056A. This cell line highly expresses both insulin and glu mRNA and the correspondent peptide hormones. We accidentally isolated novel cell lines that express extremely low levels of endogenous $\mathrm{Cdx}-2$ and glucagon in the absence of the inducer. Induced exogenous $\mathrm{Cdx}-2$ expression in these novel cell lines, however, was found to stimulate the expression of insulin mRNA and the synthesis of insulin.

\section{Materials and Methods}

\section{Materials}

Tissue culture medium and serum, and oligonucleotides were purchased from Invitrogen Life Technology (Burlington, Ontario, Canada). Radioisotopes were obtained from Amersham Pharmacia Biotech (Baie d'Urfe, Quebec, Canada). Ponasterone A and other reagents for the ecdysone-inducible gene expression system were also purchased from Invitrogen Life Technology. Forskolin, dideoxyforskolin and 3-isobutyl1-methylxanthine (IBMX) were purchased from Sigma-Aldrich (Oakville, Ontario, Canada).

\section{Plasmids}

Hamster Cdx-2 cDNA expression plasmid was originally provided by Dr German (German et al. 1992). A BamHI restriction site at the $5^{\prime}$ end and an EcoRI restriction site at the $3^{\prime}$ end were generated by a polymerase chain reaction (PCR) procedure, using the vent polymerase (New England Biolabs, Pickering, Ontario, Canada). The $\mathrm{Cdx}-2$ coding sequence was then inserted into the Pind vector, and treated with BamHI and EcoRI restriction. The new plasmid generated is designated as Pind-Cdx-2. FLATI-TK-LUC and FLATII-TK-LUC are fusion gene plasmids generated in this study, in which the expression of the luciferase (LUC) fusion gene is driven by the thymidine kinase (TK) promoter, linked with one copy of the FLAT element from either rat insulin I or rat insulin II gene. The parental TK-LUC has been utilized and described in our previous studies (Jin \& Drucker 1996, Wang et al. 2003).

\section{Cell culture, transient transfection and LUC reporter gene analysis}

The hamster pancreatic A cell line InR1-G9, the rat insulinoma cell line RIN-1056A (and its derivatives) and the hamster kidney fibroblast cell line BHK were maintained in Dulbecco's Modified Eagle's Medium (DMEM), supplemented with appropriate serum, as described previously (Drucker et al. 1994, Jin \& Drucker 1995). BHK cells were transfected by calcium phosphate precipitation. The RIN-1056A cell line was transfected by a procedure using LipofectAMINE, purchased from Invitrogen Life Technology. Cells were harvested for LUC reporter gene analysis, $20 \mathrm{~h}$ after the transfection procedure (Jin \& Drucker 1996).

\section{Establishment of the inducible $C d x-2$ gene expression cell line}

The wild-type RIN-1056A cell line was transfected with both Pind-Cdx-2 and pVgRXR plasmids. The latter encodes the ecdysone receptor $\mathrm{VgEcR}$ and the retinoid $\mathrm{X}$ receptor RXR. In the presence of the inducer ponasterone A (Pon A, final concentration $5 \mu \mathrm{M}$ ), these receptors will bind to a hybrid ecdysone response element (E/GRE), located on the Pind vector in which $\mathrm{Cdx}-2$ cDNA was inserted. After the antibiotics selection procedure, the obtained cell culture is designated as RIN-Cdx-Pool. Twenty individual clones were then isolated by the cloning ring method (Jin et al. 1997).

\section{Northern blot analysis}

Total cellular RNA was extracted with the TRIzol reagent purchased from Invitrogen Life Technology, according to the manufacturer's instruction. The method of Northern blot analysis was previously described (Jin et al. 1997).

\section{Western blot analysis}

The rabbit polyclonal antibody against the carboxylterminal portion of hamster Cdx-2 (amino acids 260-313) was generated in our previously studies (Xu et al. 1999). For Western blot analysis, whole-cell lysate containing approximately $50 \mu \mathrm{g}$ proteins from each of the cultivated cell lines was size-fractionated by $10 \%$ SDSpolyacrylamide gel electrophoresis (SDS-PAGE) and transferred to a nitrocellulose membrane. Cdx-2 immunoreactive protein was detected with an ECL Western blot analysis system (Amersham Pharmacia Biotech), according to the manufacturer's instructions, with the peroxidaselinked, antirabbit immunoglobulin as the second antibody (Jin et al. 1999). Antiactin antibody was purchased from Sigma-Aldrich.

\section{GST-fusion protein}

The generation of GST-Cdx-2 fusion protein has been described previously (Xu et al. 1999). Briefly, fulllength hamster Cdx-2 cDNA was inserted into a pGEX plasmid (pGEX4T-2, Amersham Pharmacia Biotech). After 
transforming of a host Escherichia coli strain (BL21), the expression of GST-Cdx-2 fusion protein was induced with isopropyl-1-thio- $\beta$-D-galactopyranoside (IPTG). The protein was purified with a glutathione-Sepharose 4B column. The purity of the protein was verified by Coomassie brilliant blue staining to be a single band and confirmed to contain $\mathrm{Cdx}-2$ protein by Western blot analysis.

\section{Electrophoretic mobility shift assay (EMSA)}

Nuclear protein extraction from the cultivated cell lines was done as described by Schreiber et al. (1989). EMSA using either nuclear extract or GST-Cdx-2 fusion protein was performed as described previously (Xu et al. 1999). The DNA sequence (top strain only) for the GC element of the rat glu gene promoter was as follows: $5^{\prime}$-ATTTA TATTGTCAGCGTAATATCTG-3'; FLAT elements in the rat insulin I and insulin II gene promoters were as follows: 5'-CCCCTTGTTAATAATCTAATTACCCT AGGTCTA-3' (FLAT I) and 5'-GCCCCTCTTAAGA CTCTAATTACCCTAAGGCTA-3' (FLAT II).

\section{Immunostaining}

The subconfluent RIN-1056A cell line and its derivatives grown on glass cover slips were rinsed once with PBS and fixed with paraformaldehyde (3.7\% in PBS) and permeabilized with $0 \cdot 2 \%$ Triton X-100. After they were washed with PBS containing $100 \mathrm{mM}$ glycine for $10 \mathrm{~min}$, cells were incubated with PBS containing 5\% goat serum and 1\% BSA for $60 \mathrm{~min}$ to block nonspecific binding sites. Antibodies against insulin or glucagon (1:500, DakoCytomation, Ontario, Canada) were added to the cells and left overnight at $4{ }^{\circ} \mathrm{C}$. After washing out of excessive primary antibodies, cells were incubated with Cy3-conjugated goat antirabbit immunoglobulin (Ig)G (1:500; $30 \mathrm{~min}$, Jackson ImmunoResearch Laboratories, West Grove, PA, USA), and the immunofluorescence was visualized with a Leica TCS 4D laser confocal fluorescence microscope.

\section{RIA for measuring insulin and glucagon}

The wild-type RIN-1056 cell line and its derivatives were grown in 24-well plates with $85-90 \%$ confluence. Insulin and glucagon content within the cells, treated or not treated with the inducer Pon A, was measured by RIA using the kits purchased from Linco Research (St Louis, MO, USA) (Wang \& Brubaker 2002).

\section{Results}

Establishment of the Cdx-2 gene-inducible expression system in RIN-1056A cell line

To initiate the examination of whether $\mathrm{Cdx}-2$ regulates endogenous insulin gene expression, we chose the rat insulinoma cell line RIN-1056A for the ecdysoneinducible gene expression system. This cell line was originally isolated from a radiation-induced pancreatic islet cell tumor (Chick et al. 1977, Gazdar et al. 1980, Brasier et al. 1986, Philippe et al. 1987, Tucker et al. 1996). This cell line abundantly expresses both glu and insulin gene mRNA (Brasier et al. 1986). The initial purpose of using this cell line was to use the glu gene as an internal control, because it has been previously demonstrated that endogenous glu mRNA expression is activated by overexpressing Cdx-2 in the pancreatic $\alpha$ cell line InR1-G9 (Jin et al. 1997). However, after the stable transfection and the antibiotic selection procedure, the isolated cells (designated as RIN-Cdx-Pool) substantially lost the expression of the glu mRNA (see below for detail). As shown in Fig. 1A, the RIN-Cdx-Pool cells also lost the expression of endogenous $\mathrm{Cdx}-2$ protein in the absence of the inducer (lane 2), while the expression of $\mathrm{Cdx}-2$ protein in the wild-type RIN 1056A cell line was very abundant (lane 1). After the addition of the inducer, $\mathrm{Cdx}-2$ protein expression appeared at $4 \mathrm{~h}$, and reached a maximum at 8 or $12 \mathrm{~h}$. Figure $1 \mathrm{~A}$ shows the result of a representative experiment. In this specific experiment, the induced expression of Cdx-2 mRNA was seen at $4 \mathrm{~h}$ (lane 3 ), and reached a maximum at $12 \mathrm{~h}$ (lane 5). Figure $1 \mathrm{~B}$ shows induced Cdx-2 mRNA expression in RINCdx-Pool. Induced Cdx-2 mRNA expression was accompanied by increased insulin mRNA expression at 12 and $24 \mathrm{~h}$ in this representative experiment. After $48 \mathrm{~h}$, Cdx-2 mRNA expression decreased, accompanied by a fall in insulin mRNA expression to below the level of untreated cells. Figure 1C shows that when the wild-type RIN-1056A cell line was examined, the addition of the inducer generated no notable effect on the expression of endogenous $\mathrm{Cdx}-2$, insulin or glu mRNA. Therefore, it is unlikely that the effect on $\mathrm{Cdx}-2$ and insulin mRNA expression observed in Fig. 1B in the RIN-Cdx-Pool is a nonspecific effect mediated by the inducer itself.

\section{Induced $C d x-2$ and insulin gene expression in selected $R I N-C d x$ clones}

Twenty individual clones were then isolated from the RIN-Cdx-Pool. The glu mRNA expression could not be detected in all these clones by Northern blot analysis. Among these 20 clones, five showed substantial responses to $12-\mathrm{h}$ treatment with the inducer in Cdx-2 mRNA expression. Further studies were then conducted with two of these positive clones, designated as $\mathrm{RIN-Cdx-C13}$ and RIN-Cdx-C14. As shown in Fig. 2, although the parental RIN-1056A cell line expresses endogenous Cdx-2, endogenous $\mathrm{Cdx}-2$ expression in two novel clones is undetectable by Northern blotting. These two clones do express Cdx-2 mRNA, as detected by RT-PCR (data not shown). Compared with the wild-type RIN-1056A cell line, these two clones expressed no detectable amount of 


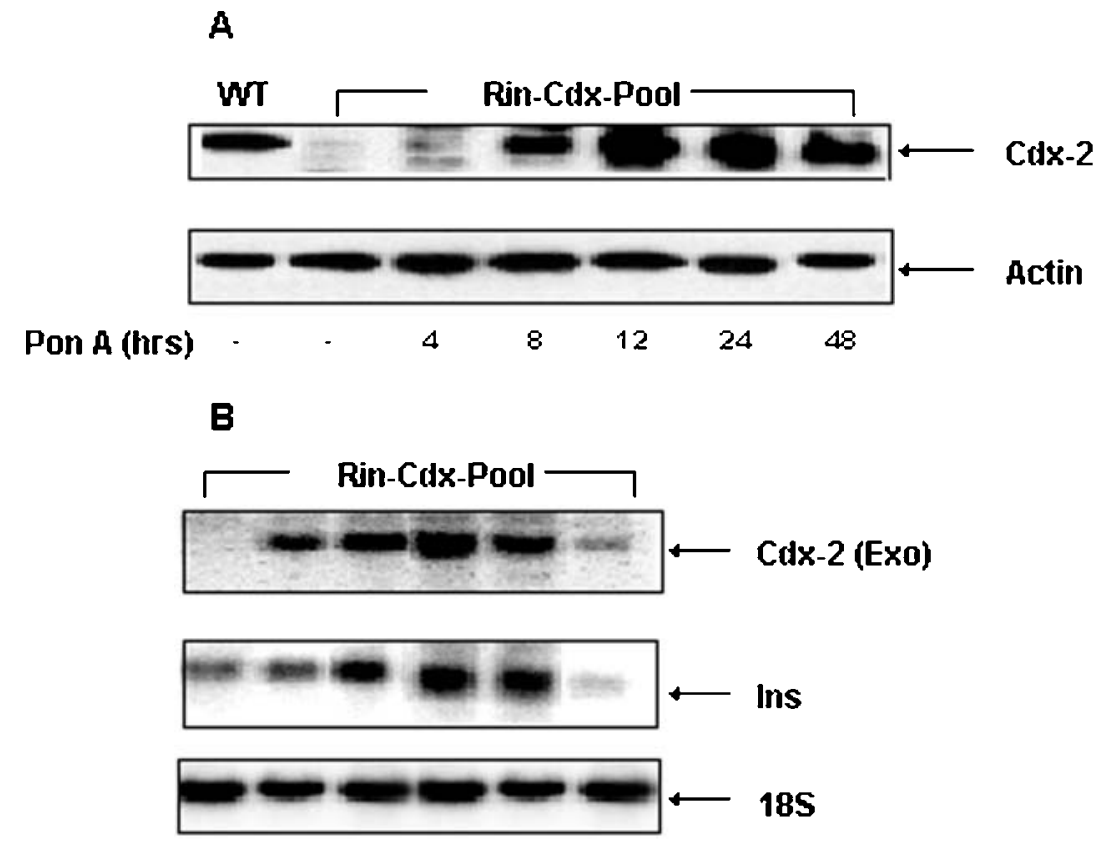

Pon A (hrs) * $\quad 4 \quad 8 \quad 12 \quad 24 \quad 48$
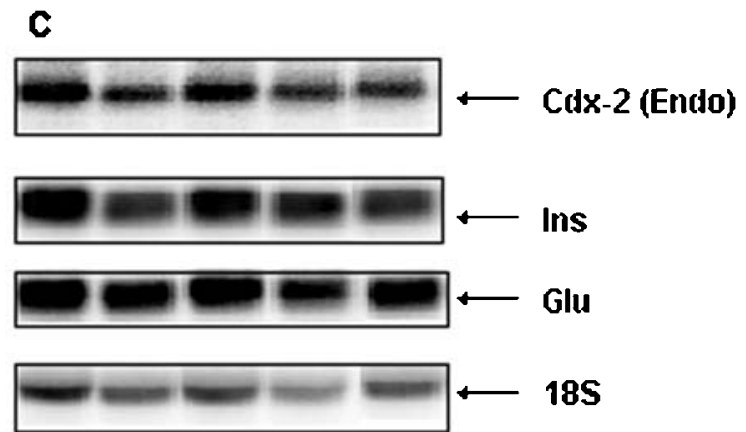

Pon A (hrs) - $\quad 4 \quad 12 \quad 24 \quad 48$

Figure 1 Establishment of the $\mathrm{Cdx}-2$ inducible expression system in the RIN-1056A cell line. (A) Western blotting shows inducible Cdx-2 protein expression. RIN-Cdx-Pool was grown in the absence or presence of $5 \mu \mathrm{M}$ Pon A for 4, 8, 12, 24 and $48 \mathrm{~h}$.

Approximately $50 \mu \mathrm{g}$ total proteins were utilized in Western blotting to examine $\mathrm{Cdx}-2$ protein expression. The same membrane was stripped, followed by hybridization with an anti- $\beta$-actin antibody (Actin, loading control). WT: wild-type RIN-1056A cell line.

(B) Northern blotting shows induced Cdx-2 mRNA expression. RIN-Cdx-Pool was grown in the absence or presence of $5 \mu \mathrm{M}$ Pon $\mathrm{A}$ for $4,8,12,24$ and $48 \mathrm{~h}$. Approximately $10 \mu \mathrm{g}$ total RNA was utilized in Northern blotting to examine exogenous Cdx-2 mRNA expression (Cdx-2 (Exo)). The same membrane was stripped, followed by hybridization with the insulin probe (Ins), and the 18-ribosome RNA probe (18S). (C) Northern blotting shows no significant effect of Pon A on $\mathrm{Cdx}-2$, insulin or glu gene expression in the wild-type RIN-1056A cells. The wild-type RIN 1056A cell line was grown in the absence or presence of $5 \mu \mathrm{M}$ Pon A for $4,12,24$ and $48 \mathrm{~h}$. Approximately $10 \mu \mathrm{g}$ total RNA were applied in Northern blotting to examine endogenous $\mathrm{Cdx}-2$ mRNA expression (Cdx-2 (Endo)). The same membrane was stripped, followed by hybridization with the insulin probe (Ins), proglucagon probe (Glu) and the 18-ribosome RNA probe (18S). 

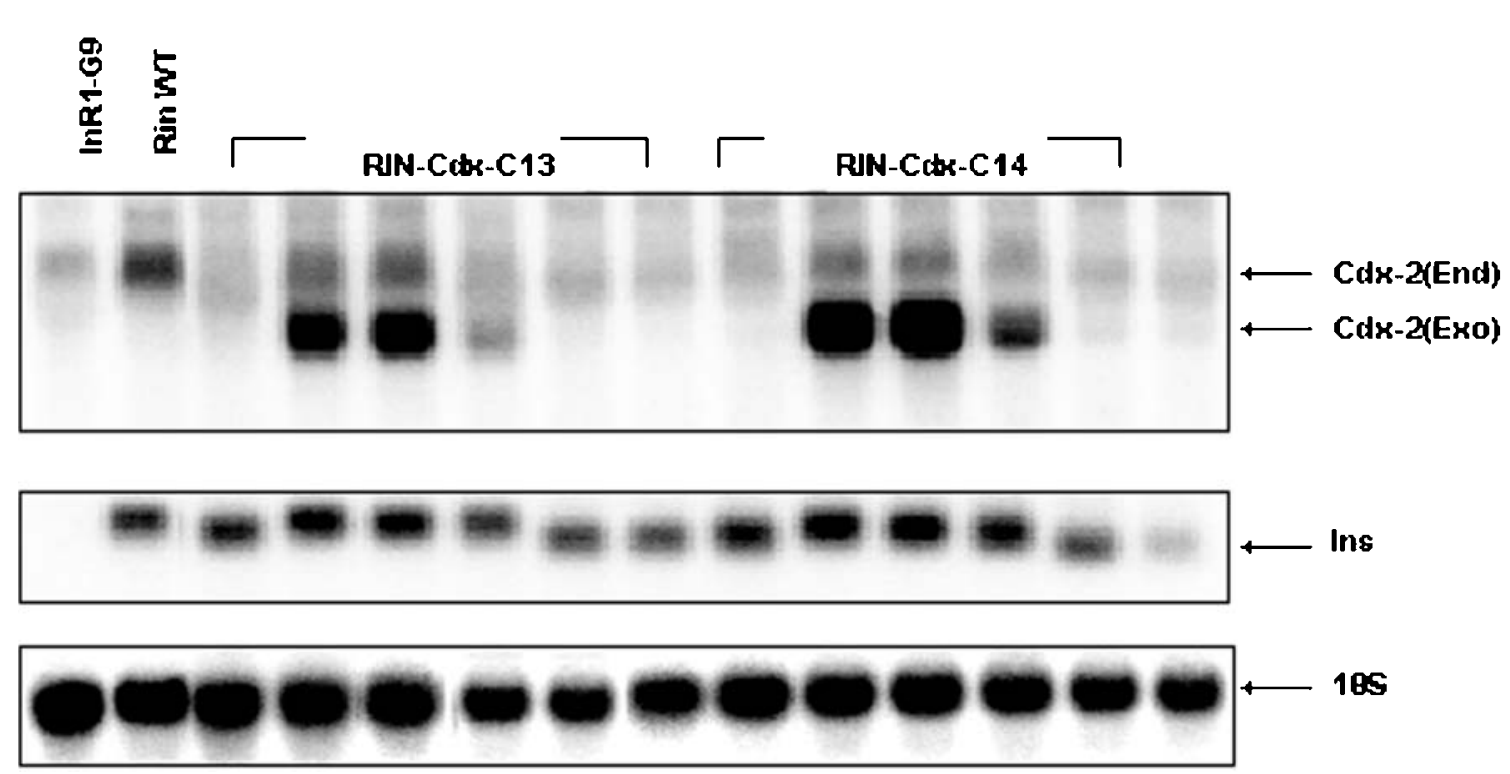

\section{- $\quad-\quad 4$ \\ $12 \quad 24 \quad 48$ \\ 4 \\ 12 \\ 24 \\ 48 \\ Pon A (hr8) \\ $\begin{array}{llllllll}\text { nia nia } & 1 & 1.84 & 1.72 & 1.29 & 0.94 & 0.91\end{array}$ \\ $\begin{array}{lllll}1.91 & 1.79 & 1.22 & 0.46 & 0.15\end{array}$ \\ Activation on Ins (fold)}

Figure 2 Effect of induced Cdx-2 expression on insulin mRNA expression in two selected RIN-Cdx-2 clones. RIN-Cdx-C13 and $\mathrm{RIN}-\mathrm{Cdx}-\mathrm{C} 14$ clones were grown in the absence or presence of $5 \mu \mathrm{M}$ Pon A for 4, 8, 12, 24 and $48 \mathrm{~h}$. Approximately $10 \mu \mathrm{g}$ total RNA were applied in Northern blotting to examine endogenous $\mathrm{Cdx}-2$ (Cdx-2 (Endo)) and endogenous Cdx-2 (Cdx-2 (Endo)) mRNA expression. The same membrane was stripped, followed by hybridization with the insulin probe (Ins) and the 18S RNA probe (18S). InR1-G9 and the parental wild-type RIN-1056A (Rin WT) were included as the positive control for endogenous Cdx-2 expression and insulin gene expression respectively. After densitometrical analyses, activation folds on insulin mRNA expression by Pon A treatment at different time courses were determined, with the untreated cells as onefold. n/a: not applicable.

glu mRNA by Northern blotting (see Fig. 4). Exogenous Cdx-2 mRNA (smaller than the endogenous Cdx-2 transcript due to its shorter $3^{\prime}$-untranslated region) expression was found to be rapidly and markedly induced after 4-h Pon A treatment (lanes 4 and 5 for RIN-Cdx-C13, and lanes 10 and 11 for RIN-Cdx-C14). At $12 \mathrm{~h}$, exogenous Cdx-2 expression dropped, and at 24 and $48 \mathrm{~h}$, its expression is below the detection level. Induced exogenous $\mathrm{Cdx}-2$ expression was associated with enhanced insulin mRNA expression in both RIN-Cdx-C13 and RIN-Cdx-C14 cell lines (Fig. 2). We observed that at 4 and $8 \mathrm{~h}$ after the Pon A treatment, endogenous Cdx-2 expression appeared in both cell lines (lanes 4 and 5 , and lanes 10 and 11), suggesting that exogenous Cdx-2 may activate endogenous $\mathrm{Cdx}-2 \mathrm{mRNA}$ expression. We noticed that the expression of tubulin mRNA was also activated after the induction procedure. The mouse $18 \mathrm{~S}$ RNA probe was then utilized in the Northern blotting as the loading control (Fig. 2).

\section{Induced insulin synthesis}

We then examined whether insulin synthesis in the novel RIN-1056A cell lines could be activated by induced
Cdx-2 expression. Representative data are shown in Fig. 3. Treating the wild-type RIN-1056A cell line with Pon A generated no significant effect on insulin content in the cell lysates. However, when the RIN-Cdx-C14 clone was examined, insulin content increased significantly after 4- and 8-h Pon A treatment.

\section{Lack of glu expression in the new RIN-1056 A cell lines}

As shown in Fig. 4A, RIN-Cdx-Pool, RIN-Cdx-C13 and RIN-Cdx-C14 expressed no detectable glu mRNA in the absence of the inducer. In contrast, glu mRNA was abundantly expressed in the pancreatic InR1-G9 and the wild-type RIN-1056A cell lines. Our speculative explanation of the loss of Cdx-2 and glu expression in these new cell lines is presented in the Discussion section. Fig. 4B shows the detection of glucagon hormone by RIA in both the hamster pancreatic $\alpha$ cell line InR1-G9 and the parental RIN-1056A cell line. The two novel RIN1056A cell lines, however, do not express glucagon. In addition, we could not detect glucagon in the medium in either the parental RIN 1056A cell line or the two novel clones, and lowering the glucose concentration generated no substantial effect on glucagon content in the wild-type 


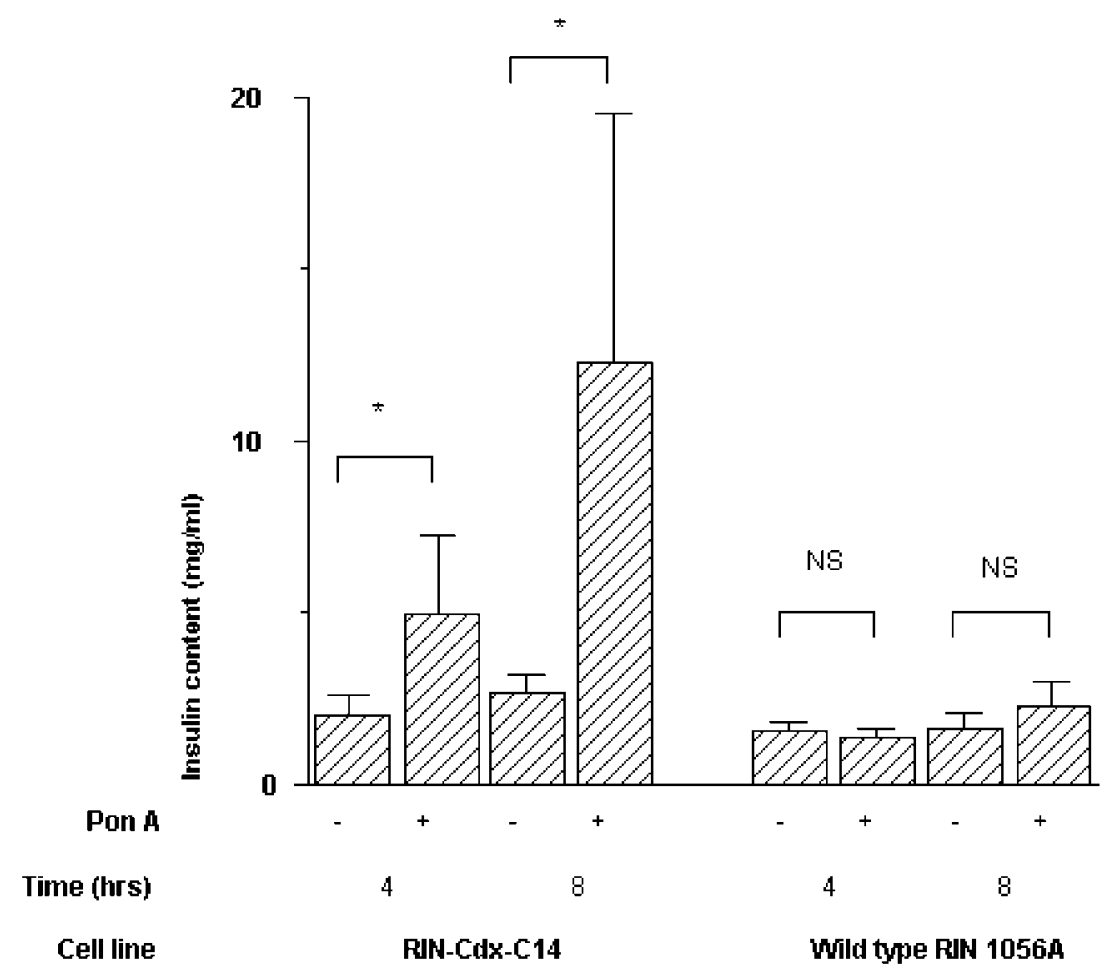

Figure 3 The effect of induced $\mathrm{Cdx}-2$ expression on insulin hormone synthesis. The RIN-Cdx-C14 cell line and the parental wild-type RIN-1056A cell line were grown in the absence or presence of $5 \mu \mathrm{M}$ Pon A for 4 and $8 \mathrm{~h}$. Insulin content in cell lysates was measured by RIA. ${ }^{*} P<0 \cdot 05$ as reported by Student's $t$-test, and NS (not significant). $n=4$.

RIN-1056A cell line, as consistent with a previous report (Poitout et al. 1996). Figure 4C shows the results of immunostaining for the detection of insulin and glucagon in the absence of the inducer. Insulin was abundantly expressed in both the parental RIN-1056A cell line, and in the two novel cell clones. Glucagon expression, however, was substantially reduced in both RIN-Cdx-C13 and $\mathrm{RIN}-\mathrm{Cdx}-\mathrm{C} 14$ cell clones.

Binding of Cdx-2 protein to the FLAT elements of the insulin gene promoters

Hamster $\mathrm{Cdx}-2$ was isolated from an insulinoma cell line cDNA expression library, using the rat insulin I gene FLAT element as the probe (German et al. 1992). A similar, but not identical FLAT element is also located on the rat insulin II gene promoter. We conducted EMSA, using both the Cdx-2-GST fusion protein and the nuclear extract from the wild-type RIN-1056A cell line, against the oligonucleotide probes designated as FLAT I and FLAT II (see Materials and methods section for their DNA sequences). As shown in Fig. 5A, Cdx-2-GST-fusion protein forms two complexes (designated as C1 and C2) with ${ }^{32} \mathrm{P}-\mathrm{dCTP}-\mathrm{labeled}$ FLAT I or FLAT II probes. This result is similar to our previous observation that Cdx-2GST forms two complexes with an enhancer element of the mouse Cdx-2 promoter (Xu et al. 1999), and the GC element of rat glu promoter (unpublished data of Liu, Zhao, Branch and Jin). Figure $5 \mathrm{~A}$ also shows that the formation of these two complexes could be inhibited by unlabeled FLAT I, FLAT II or GC probes. Furthermore, anti-Cdx-2 antibody inhibited the formation of the two complexes and generated 'super-shifted' complexes. Figure 5B shows that nuclear extract from the wild-type RIN-1056A cells forms four DNA-protein complexes, under our experimental conditions, with the FLAT I probe (lane 1). The unlabeled FLAT I or FLAT II probe was found to compete effectively the formation of all the four complexes, indicating the similar binding capability of these two enhancer elements (lanes 2 and 3). The GC subelement of the rat glu gene promoter G1 enhancer has been demonstrated previously by several groups to bind to Cdx-2 (Jin \& Drucker 1996, Laser et al. 1996, Hussain \& Habener 1999). The addition of unlabeled GC probe did not affect the formation of the three major complexes, C1, $\mathrm{C} 2$ and C4 (lanes 4 and 5). However, the formation of the C3 complex was abolished (lanes 4 and 5), indicating that C3 may contain $\mathrm{Cdx}-2$. Lane 6 shows that preincubation of the nuclear extract with the anti-Cdx-2 antibody 


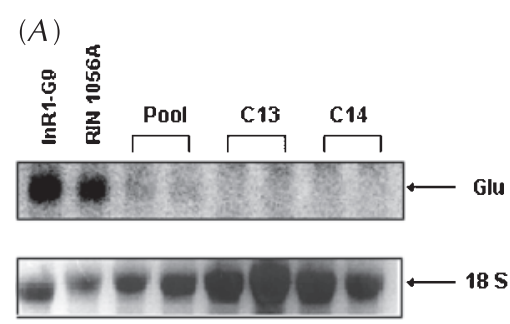

$(B)$

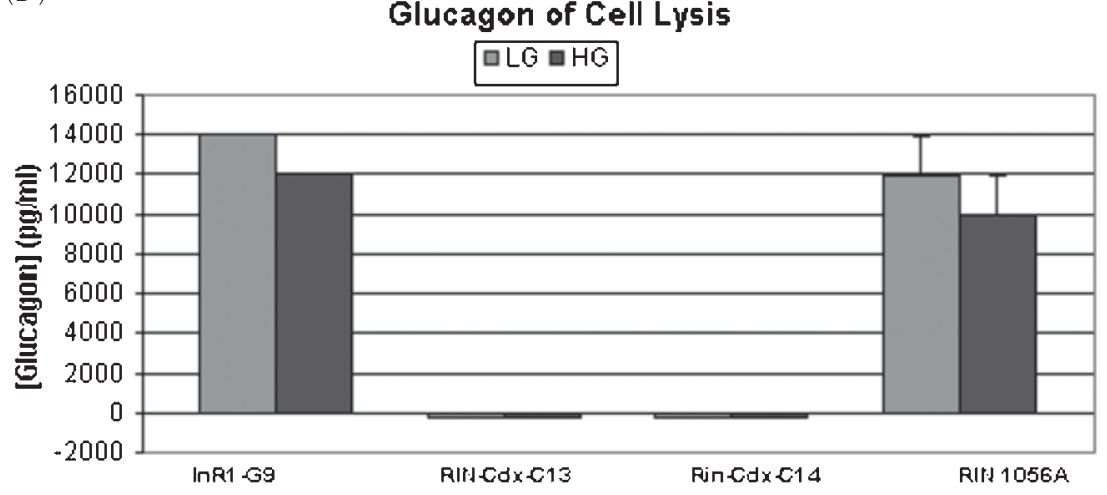

(C)

\section{Glucagon}
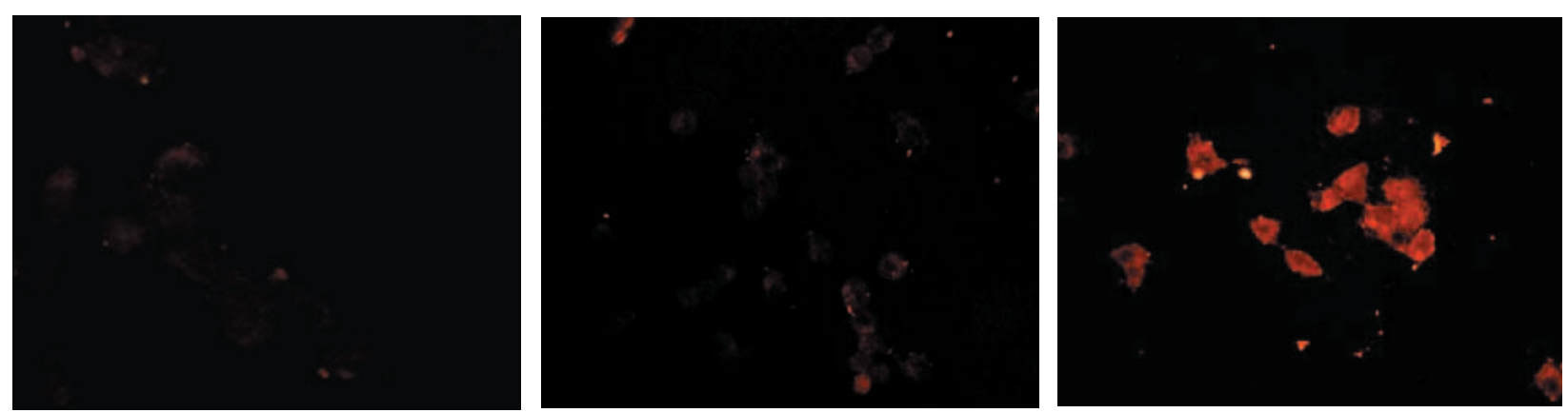

\section{Insulin}

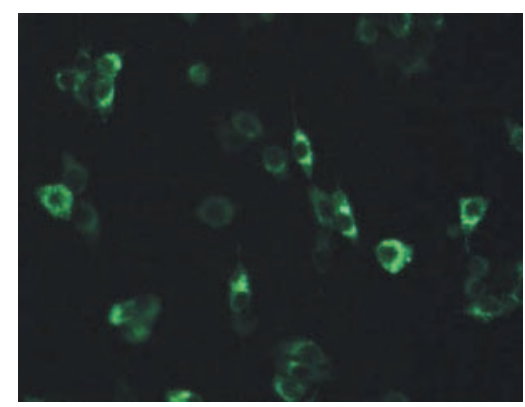

RIN-Cdx-C13

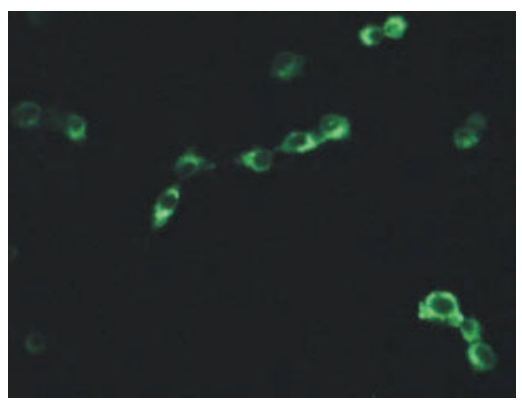

RIN-Cdx-C14

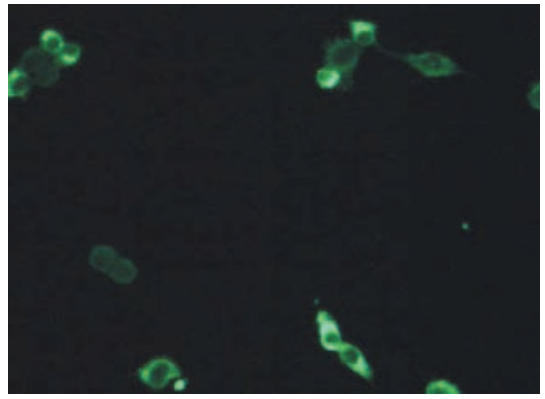

RIN 1056A

Figure 4 Loss of glu expression in the established Cdx-2-inducible expression RIN-1056A cell lines. (A) Loss of glu mRNA expression. Total RNA from untreated InR1-G9, wild-type RIN-1056A, RIN-Cdx-Pool (Pool), RIN-Cdx-C13 (C13) and RIN-Cdx-C14 (C14) cell lines was used in Northern blotting to examine glu mRNA (Glu) expression. The same membrane was stripped, followed by hybridization with the 18S RNA probe (18S). (B) Loss of glucagon hormone expression examined by RIA. Indicated cell lines were grown in the medium with low $(5 \mathrm{mM})$ or high $(11 \mathrm{mM})$ glucose. Glucagon content in cell lysates was measured by RIA $(n=4)$. (C) Examination of glucagon and insulin expression by immunostaining. Red: glucagon; green: insulin.

prevented the formation of the C3 complex, and generated a super-shifted complex. Lane 7 shows that an unrelated antibody generated no such effects. Taken together, these observations indicate that $\mathrm{Cdx}-2$ produced in the wildtype RIN-1056A cell line is capable of binding to the FLAT elements from either insulin I or insulin II genes. 
$(A)$

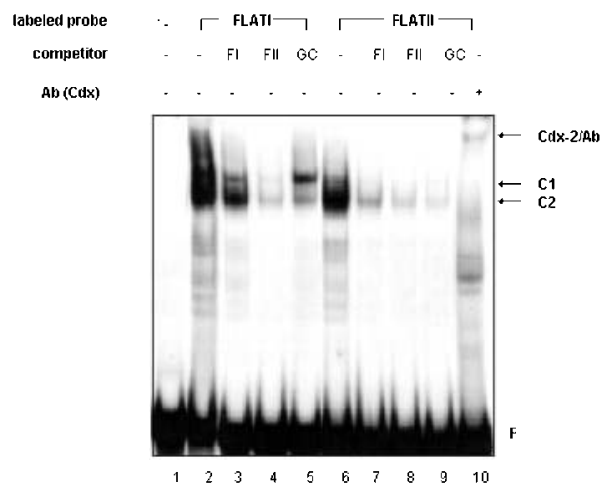

(B)

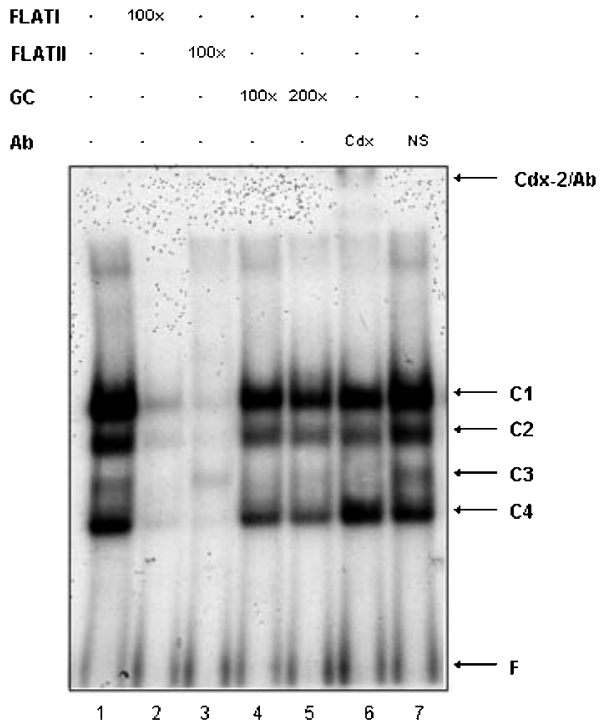

Figure 5 Examination of the binding of $\mathrm{Cdx}-2$ to the FLAT elements by EMSA. (A) Cdx-2-GST forms two complexes with both FLAT I (FI) and FLAT II (FII). An amount of 4 ng Cdx-2-GST fusion protein was incubated with indicated probe. Competition assay was conducted with a 100 -fold unlabeled probe. Super-shifting was conducted by incubating $2 \mu \mathrm{l}$ anti-Cdx-2 antibody with the reaction mixture for $1 \mathrm{~h}$ on ice before the addition of the labeled probe. GC: a subelement of the rat glu gene G1 enhancer element, which binds to native Cdx-2 (9); F: free probe. (B) Examination of the binding of the wild-type RIN-1056 A cell nuclear extract to the FLAT I element. An amount of $5 \mu \mathrm{g}$ nuclear protein from untreated wild-type RIN-1056A cell line was incubated with labeled FLAT I probe, in the absence or presence of indicated unlabeled competitor, anti-Cdx-2 antibody $(\mathrm{Cdx})$, or preimmune serum (NS). DNA-protein complexes are designated as C1-C4. F: free probe.

\section{Activation of FLAT-TK-LUC fusion genes by Cdx-2 cotransfection}

We then constructed the FLAT-TK-LUC fusion genes, in which one copy of either FLAT I or FLAT II was inserted into the TK-LUC. The BHK fibroblasts, which have been utilized previously in our group as the naive cell system in examining the activation of $\mathrm{Cdx}-2$ on glu gene promoter (Jin \& Drucker 1996), were cotransfected with Cdx-2 cDNA and the parental TK-LUC, or TK-LUC with a correspondent FLAT element. As shown in Fig. 6, without Cdx-2 cotransfection, basal activities of FLAT I-TK-LUC and FLAT II-TK-LUC are approximately fivefold and threefold higher than that of the parental TK-LUC respectively, indicating that FLAT nucleotide sequences do serve as the enhancer elements in this system. Cotransfecting with $\mathrm{Cdx}-2$ cDNA resulted in another approximately threefold activation.

\section{Activation of $C d x-2$ expression by forskolin/IBMX treatment}

In conducting another line of research, we noticed the activation of $\mathrm{Cdx}-2$ protein and mRNA expression by the second messenger cAMP (assessed by Western and Northern blotting after treating cells with forskolin/ IBMX) in pancreatic and gut proglucagon-producing endocrine cells (Chen et al. 2005). To initiate the assessment of the physiologic relevance of activation of insulin gene expression by overexpressing $\mathrm{Cdx}-2$, we asked whether Cdx-2 expression in the wild-type RIN-1056A cell line could be activated by forskolin/IBMX treatment. If it could, we asked whether the activation of $\mathrm{Cdx}-2$ expression by forskolin/IBMX would be accompanied by stimulated insulin gene expression. Our pilot experiments indicated that $\mathrm{Cdx}-2$ protein expression could be activated after treatment with $1 \mu \mathrm{M}$ forskolin and $10 \mu \mathrm{M}$ IBMX for $6 \mathrm{~h}$ (data not shown). Further examinations were then conducted with these concentrations of the chemicals. Figure 7 shows our representative blots and statistical results on three individual experiments. In the wild-type RIN-1056A cell line, both Cdx-2 protein (Fig. 7A) and Cdx-2 mRNA expression (Fig. 7B) could be activated by forskolin/IBMX. Activated Cdx-2 expression was accompanied by approximately twofold activation on insulin mRNA expression (Fig. 7B). Both RIN-Cdx-C13 and RIN-Cdx-C14 did not express endogenous Cdx-2, while their exogenous $\mathrm{Cdx}-2$ expression could not be further stimulated by forskolin treatment (data not shown). We then directly examined the effect of forskolin treatment on insulin mRNA expression in these two cell lines, in the absence of the inducer Pon A. As shown in Fig. 8, 


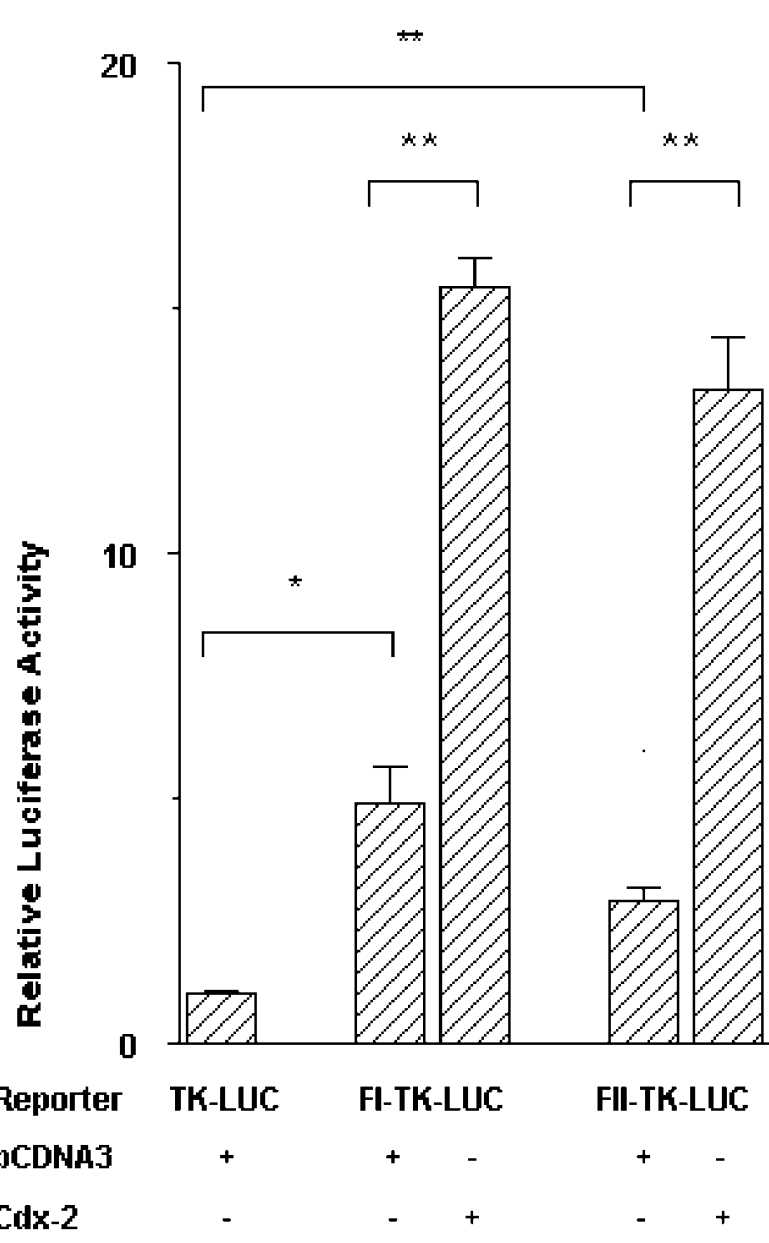

Figure $6 \mathrm{Cdx}-2$ cotransfection activates the expression of the fusion promoters containing FLAT I and FLAT II. BHK cells were cotransfected with $3 \mu \mathrm{g}$ TK-LUC, or TK-LUC with one copy of FLAT I (FI-TK-LUC) or FLAT II (FII-TK-LUC), plus $3 \mu \mathrm{g}$ pCDNA3 or pcDNA3-Cdx-2. Cells were harvested for LUC reporter gene analysis $20 \mathrm{~h}$ after the transfection. Relative LUC activity was calculated as the -fold increase with the activity obtained, using TK-LUC and pcDNA3 as onefold in the untreated cells defined as onefold (mean S.E., $n=3$ ). ${ }^{*} P<0 \cdot 05 ;{ }^{* *} P<0 \cdot 01$ as reported by the Student's $t$-test.

although forskolin/IBMX was still able to stimulate insulin mRNA expression in these two cell lines, the activations were attenuated compared with the wildtype cell line. This indicates that $\mathrm{Cdx}-2$ may serve as a major mediator for cAMP in regulating insulin gene expression.

\section{Discussion}

Shortly after the discovery of homeobox genes in 1984 , endocrinologists began to explore the role of these 'master' control genes in hormone synthesis and the genesis of hormone-producing cells (Ingraham et al. 1988, Karlsson et al. 1990, Dong et al. 1991). One important phenomenon is that HD proteins, like many other 'tissue-specific' transcription factors, are never expressed as specifically as their downstream target genes (Graef \& Crabtree 1997). In pancreatic islets, $\mathrm{Pdx}-1$ may regulate the expression of both insulin and somatostatin genes (Leonard et al. 1993, Ohlsson et al. 1993, Miller et al. 1994, Lu et al. 1996), and several other $\beta$-cell specific genes (McKinnon \& Docherty 2001). Pax6, however, is expressed in three major types of hormone-producing endocrine cells in pancreatic islets, and it could be involved in regulating the expression of insulin, glu and somatostatin genes (Sander et al. 1997, St-Onge et al. 1997, Andersen et al. 1999, Hussain \& Habener 1999).

Although the existence of $\mathrm{Cdx}-2$ in mammals was first reported by James and Kazenwadel in 1991, the complete cDNA sequence for mouse Cdx-2 was not available until 1994 (James et al. 1994, Suh et al. 1994). In 1992, however, German et al. obtained a complete caudal gene cDNA, namely, Cdx-3. It was isolated from the hamster insulinoma cell line HIT-T15 cDNA expression library, using the FLAT enhancer element as the probe. Now it is generally accepted that $\mathrm{Cdx}-3$ represents the hamster homolog of mouse Cdx-2. To avoid further confusion in the literature, we began to abandon the use of the terms 'Cdx-3' and 'Cdx-2/3' (Jin \& Li 2001). German et al. found that $\mathrm{Cdx}-2$ is expressed in three pancreatic islet cell lines, including both $\alpha \mathrm{TC}$ and $\beta \mathrm{TC}$. We demonstrated later that $\mathrm{Cdx}-2$ is also expressed in pancreatic and gut glu-producing InR1-G9, GLUTag and STC-1 cell lines (Jin \& Drucker 1996). In addition, we confirmed the expression of $\mathrm{Cdx}-2$ mRNA in mouse pancreas by Northern blotting and by RT-PCT (data not shown).

German et al. (1992) reported that Cdx-2 cDNA cotransfection activated a LUC fusion promoter containing five copies of the FLAT element (designated as FLAT I in our study), or the correspondent nucleotide sequence from the rat insulin II gene (designated as FLAT II in our study), or FLAT-related element in human IAPP gene. No further study has been conducted to examine the effect of $\mathrm{Cdx}-2$ on endogenous insulin gene expression. We and two other groups, however, demonstrated that Cdx-2 can bind to the G1 enhancer of the glu promoter, and activate glu promoter and endogenous glu mRNA expression in the pancreatic InR1-G9 cells (Jin \& Drucker 1996, Laser et al. 1996, Hussain \& Habener 1999). In adults, Cdx-2 is also expressed in differentiated intestinal epithelia of nonendocrine origin, and regulates the expression of nearly a dozen other potential target genes (Uesaka et al. 2004).

We determined to use the ecdysone-inducible gene expression system to examine the implication of $\mathrm{Cdx}-2$ in regulating endogenous insulin gene expression in vitro, because this system is considered less leaky than other available inducible gene expression systems (Patrick et al. 2001, Graham 2002, Uesaka et al. 2004). Indeed, in the 
(A)

\section{Western Blotting}
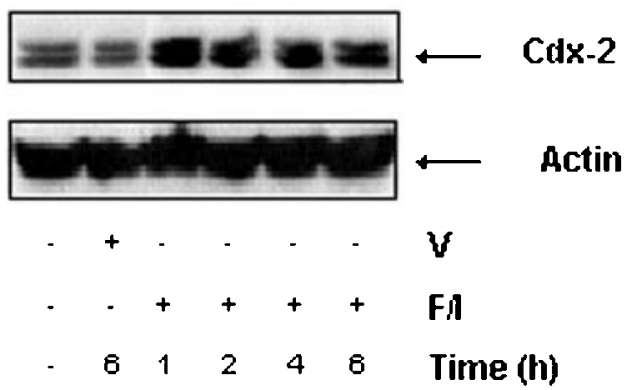

(B)

\section{Northern Blotting}

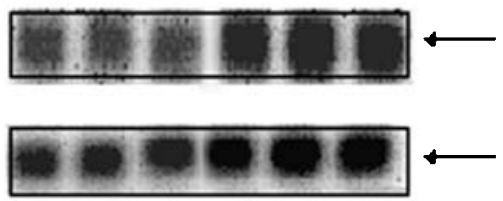

$\mathrm{Cdx}-2$

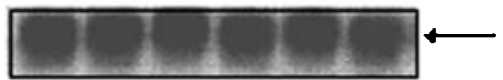

$18 S$

Ins

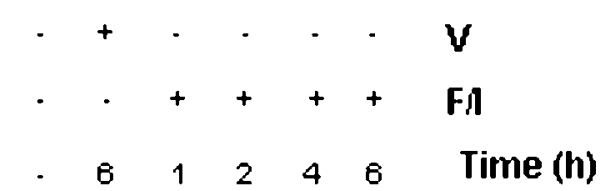

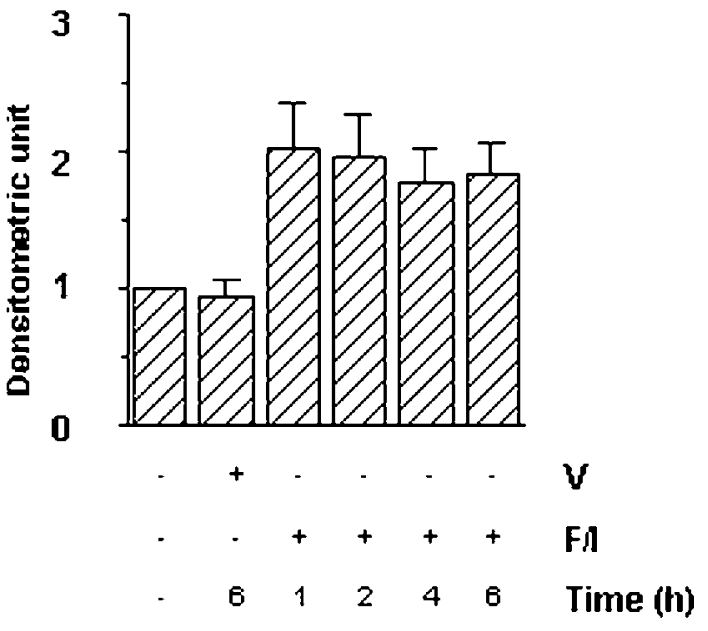
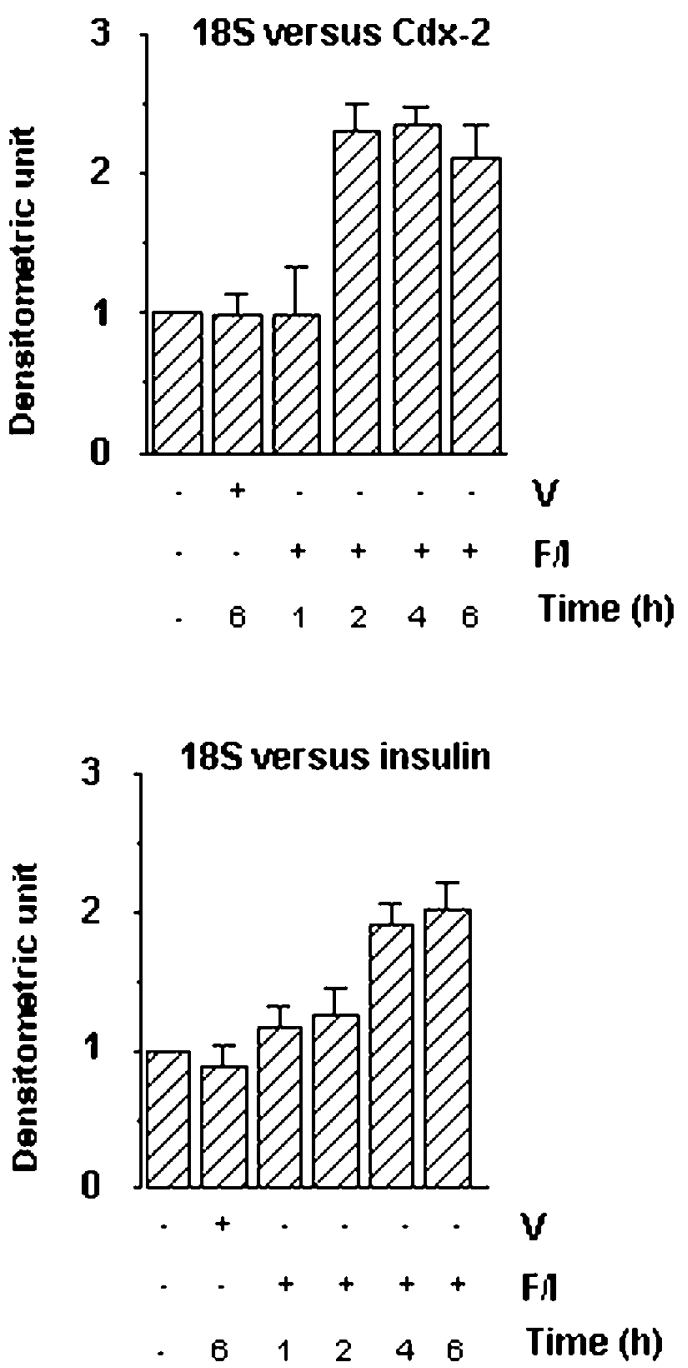


\section{A. RIN-Cdx-C13}
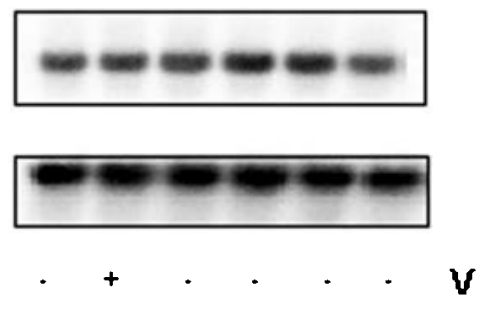

$\cdot++++F_{\|}$

$\begin{array}{llllll}6 & 1 & 2 & 4 & 6 & \text { Time (h) }\end{array}$
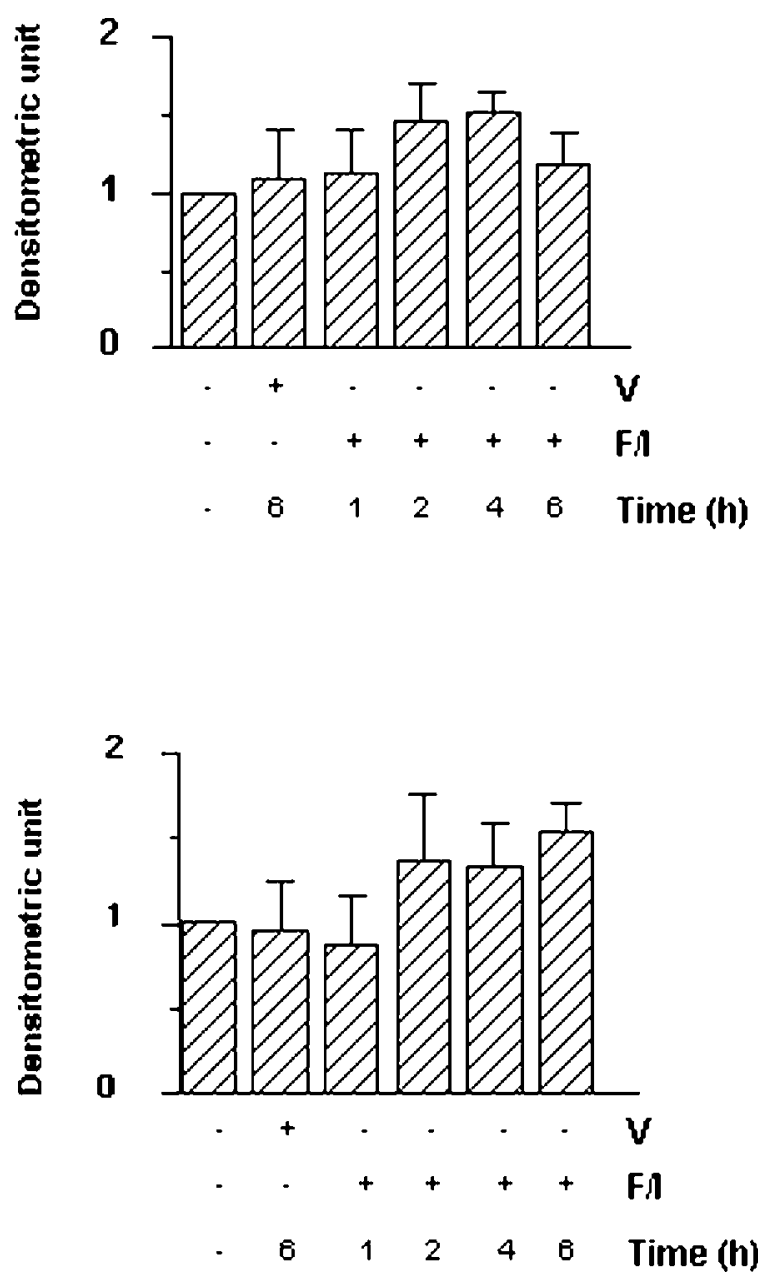

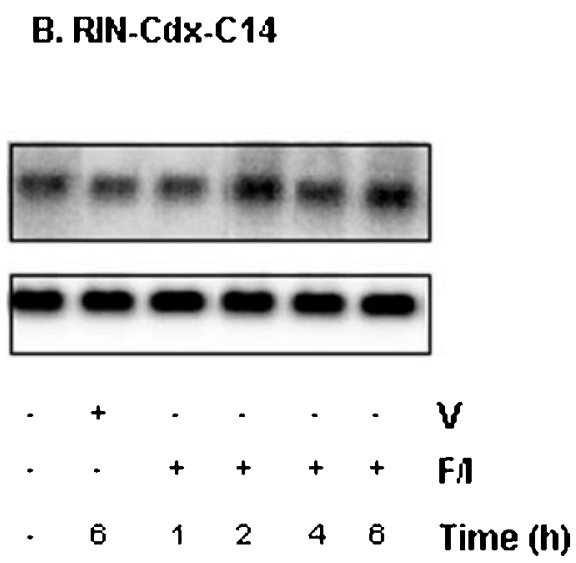

Figure 8 Attenuated activation on insulin mRNA expression by forskolin/IBMX treatment in two novel cell lines of RIN 1056A. RIN-Cdx-C13 (A) and RIN-1056-C14 (B) cells were treated with $1 \mu \mathrm{M}$ forskolin plus $10 \mu \mathrm{M}$ IBMX (F/I) for indicated period before harvest to assess insulin mRNA expression by Northern blotting (left panels). 18S ribosome RNA was utilized as the loading control. After the densitometry analyses, activation on insulin mRNA expression by forskolin/IBMX treatment at different time courses was presented as -fold, with the cells receiving no treatment as onefold (right panels). The experiments were independently performed three times.

absence of the inducer, both RIN-Cdx-Pool and two isolated individual clones showed no detectable exogenous $\mathrm{Cdx}-2$ expression. We found that after the induction of $\mathrm{Cdx}-2$ expression, insulin gene expression increases, accompanied by enhanced insulin hormone synthesis. Our study therefore shows for the first time that Cdx-2 may activate endogenous insulin gene expression.

Two observations made us ask whether $\mathrm{Cdx}-2$ directly activates insulin expression by indirect mechanisms. First, although the addition of the inducer generated extremely

Figure 7 Activation of $\mathrm{Cdx}-2$ and insulin gene expression by forskolin/IBMX treatment. (A) Activation of Cdx-2 protein expression by forskolin/IBMX treatment. The wild-type RIN-1056A cells were treated with $1 \mu \mathrm{M}$ forskolin plus $10 \mu \mathrm{M}$ IBMX for indicated period before harvest to assess the effect on $\mathrm{Cdx}-2$ protein expression by Western blotting (left panel; right panel represents the densitometry results from the left panel). Actin was served as the loading control. V: vehicle; F/I: forskolin plus IBMX. The experiments were independently performed three times. (B) Activation of Cdx-2 and insulin mRNA expression by forskolin/IBMX treatment. The wild-type RIN-1056A cells were treated with $1 \mu \mathrm{M}$ forskolin plus $10 \mu \mathrm{M}$ IBMX for indicated period before harvest to assess the effect on Cdx-2 and insulin mRNA expression by Northern blotting (left panel; right panel represents the densitometry results from the left panel). 18S ribosomal RNA (18S) served as the loading control. V: vehicle; F/I: forskolin plus IBMX. The experiments were independently performed three times. 
high amounts of Cdx-2 mRNA and protein expression within 4 and $8 \mathrm{~h}$, both insulin mRNA expression and insulin hormone synthesis were increased by only approximately twofold. Second, induced $\mathrm{Cdx}-2$ expression was also accompanied by enhanced tubulin mRNA expression, and GDPAH expression (data not shown) in these novel cell lines. To initiate the examination of the potential mechanisms involved, we asked two specific questions. First, we asked whether $\mathrm{Cdx}-2$ binds to the insulin promoter FLAT elements. German et al. (1992) found that $\mathrm{Cdx}-2$ produced by an in vitro transcription and translation approach can form one complex with FLAT (designated FLAT I in this study) or R2 (designated FLAT II in this study). We show here that Cdx-2-GST fusion protein forms a major complex (C2) and a minor complex (C1) with either FLAT I or FLAT II. Because the formation of these complexes could be attenuated by unlabeled FLAT I, FLAT II or GC probe, or by antiCdx-2 antibody, we believe that $\mathrm{Cdx}-2$ does have the capability to bind to the FLAT element of insulin genes. GST-fusion protein alone, however, is evidently not able to bind to any of the three enhancer-elements (data not shown). The FLAT element contains two AT-rich motifs, namely, FLAT-F and FLAT-E (German et al. 1992). It is possible that both motifs can bind to Cdx-2-GST, and each of the two complexes may represent the binding of Cdx-2 to a given AT-rich motif. A similar observation was made before in studying the binding of Cdx-2-GST to the enhancer element of the mouse $\mathrm{Cdx}-2$ promoter $(\mathrm{Xu}$ et al. 1999). We then conducted EMSA, and our data indicated that, although Cdx-2 produced in RIN1056A cells can bind to the FLAT I probe, the binding capability is relatively lower.

The second question we asked is whether Cdx-2 activates a fusion gene promoter containing a FLAT element. German et al. (1992) made LUC fusion gene constructs containing five copies of the FLAT element, and observed substantial activation on these fusion promoters by $\mathrm{Cdx}-2$ cDNA cotransfection. To avoid the possibility that using multiple copies of a cis-element may generate artifacts in reporter gene analysis, we generated the fusion promoters with only one copy of FLAT I or FLAT II. We found that a single copy of FLAT I or FLAT II did serve as the enhancer element in medicating the response to $\mathrm{Cdx}-2$ cDNA cotransfection. These observations suggest that $\mathrm{Cdx}-2$ activates insulin expression by directly binding to the insulin promoter FLAT elements. However, we cannot eliminate the existence of indirect mechanisms, and it will be interesting to examine whether, in intact cells, Cdx-2 binds to the FLAT elements by the chromatin immunoprecipitation (ChIP) approach. It should also be pointed out that multiple cis- and trans-elements are involved in regulating insulin expression (Sander \& German 1997, McKinnon \& Docherty 2001, Melloul et al. 2002). The $\beta$ cell-specific transcription factor Pdx-1 can bind to several cis-elements on both insulin I and insulin II promoters, including the FLAT elements (Melloul 2004). It will be interesting to compare the binding affinities of $\mathrm{Pdx}-1$ and $\mathrm{Cdx}-2$ on the two binding motifs on the FLAT elements in vitro, and in intact cells, and to investigate whether and how these two proteins work together to regulate insulin gene expression. Furthermore, a recent report by Ritz-Laser et al. (2003) indicates that ectopic expression of Pdx-1 inhibits glucagon gene expression. The authors suggest that the inhibition is mediated by protein-protein interactions. Whether overexpression of Cdx-2 would help the recruitment of Pdx-1 into the FLAT elements of insulin gene promoters by protein-protein interaction should be investigated.

Another interesting observation is that the novel cell lines generated in this study lose the expression of endogenous $\mathrm{Cdx}-2$ and glu mRNA. The parent RIN-1056A cell line can express genes that encode insulin, proglucagon, somatostatin and the glycoprotein precursor of angiotensin II (Chick et al. 1977, Gazdar et al. 1980, Brasier et al. 1986, Philippe et al. 1987, Tucker et al . 1996). We speculate that loss of $\mathrm{Cdx}-2$ and glu expression indicates that this cell line contains multiple populations, and the plasmid DNA transfection and antibiotics selection procedures eliminated the one that highly expresses glu and $\mathrm{Cdx}-2$. If this is true, we should be able to detect, by immunostaining, the cells in the parental RIN 1056A cell line that express insulin, but not glucagon. We conducted double immunostaining against the wild-type RIN1056A cell line, and our result was not very supportive. Most, if not all, cells showed the expression of both insulin and glucagon (data not shown). We then examined the expression of glucagon hormone by RIA. It is clear that the two selected clones did not express glucagon hormone, while the parental RIN-1056A cell line did. Although our immunostaining results in Fig. 4C also showed substantially reduced glucagon hormone expression in two selected clones, some residual glucagon staining was still observable. It is true that the inducible gene expression system in this study is not leaky. However, the introduction of this system into the RIN-1056A cell line may affect the expression $\mathrm{Cdx}-2$ and glu by a yet unknown mechanism. Further studies are needed to answer this intriguing question.

After studying the change of gene expression profiles in these novel inducible Cdx-2 expression RIN-1056A cell lines, we were able to contribute some further discussion and speculation on the role of $\mathrm{Cdx}-2$ in regulating glu and insulin gene expression.

Is $\mathrm{Cdx}-2$ expression essential for glu expression in pancreatic $\alpha$ cells? In addition to observations made previously (Jin \& Drucker 1996, Laser et al. 1996, Jin et al. 1997, Hussain \& Habener 1999), supportive evidence from this study is that the novel cell lines lose the expression of endogenous $\mathrm{Cdx}-2$, accompanied by loss of glu expression. On the other hand, in these novel cell lines, induced overexpression of $\mathrm{Cdx}-2$ cannot provoke 
glu mRNA expression. One may suggest that the novel cell lines may represent the cell lineage that completely lost the capability to re-express the glu gene. Temporal and spatial expression of HD proteins affecting the commitment of cell lineage in pancreatic islets has been documented. For example, Hussain et al. (2002) reported that ectopic misexpression of the POU HD protein Brn-4 by $\mathrm{Pdx}-1$ promoter in transgenic mice resulted in ectopic expression of the glu gene in insulin-expressing pancreatic $\beta$ cells, while misexpressing Brn-4 by rat insulin II promoter did not.

Obviously, Cdx-2 is not an essential factor in basal insulin gene expression. In the absence of the inducer, the novel cell lines we obtained did not express an appreciable amount of endogenous $\mathrm{Cdx}-2$, while their insulin mRNA expression and hormone synthesis were comparable with that of the parental RIN-1056A cell line (Fig. 2). We can conclude that, after the induction of Cdx-2 expression, an approximately twofold activation of insulin gene expression and insulin hormone synthesis was observed. Is this activation physiologically important? We demonstrate here that $\mathrm{Cdx}-2$ expression can be activated by forskolin/ IBMX treatment, and activated $\mathrm{Cdx}-2$ expression is accompanied by moderately enhanced insulin gene expression. The intracellular levels of the second messenger cAMP in the $\beta$ cells may perpetuate in response to physiologic and developmental signals. One may speculate that Cdx-2 may serve as a mediator for cAMP in regulating hormone synthesis and the differentiation and maturation of hormone-producing cells. Therefore, although $\beta$ cells may not need to express high amounts of $\mathrm{Cdx}-2$ for its basal level insulin gene expression, $\mathrm{Cdx}-2$ could still play important role in regulating insulin gene expression temporally and spatially.

\section{Acknowledgements}

We thank Dr Michael German for providing the original Cdx-2 (Cdx-3) cDNA and Dr Peixiang Wang for his suggestions. This work was supported by grants from the Canadian Institutes of Health Research (CIHR, MOP$62745 \mathrm{G}$ ) and Canadian Diabetes Association (CDA, 1198 ) to TJ. The authors declare that there is no conflict of interest that would prejudice the impartiality of this scientific work.

\section{References}

Andersen FG, Jensen J, Heller RS, Petersen HV, Larsson LI, Madsen OD \& Serup P 1999 Pax6 and Pdx1 form a functional complex on the rat somatostatin gene upstream enhancer. FEBS Letters $\mathbf{4 4 5}$ 315-320.

Brasier AR, Philippe J, Campbell DJ \& Habener JF 1986 Novel expression of the angiotensinogen gene in a rat pancreatic islet cell line. Transcriptional regulation by glucocorticoids. Journal of Biological Chemistry 261 16148-16154.
Chen L, Wang P, Andrade CF, Zhao IY, Dube PE, Brubaker PL, Liu M \& Jin T 2005 PKA independent and cell type specific activation of the expression of caudal homeobox gene Cdx-2 by cyclic AMP. European Journal of Biochemistry (in press).

Chick WL, Warren S, Chute RN, Like AA, Lauris V \& Kitchen KC 1977 A transplantable insulinoma in the rat. PNAS 74 628-632.

Dong J, Asa SL \& Drucker DJ 1991 Islet cell and extrapancreatic expression of the LIM domain homeobox gene isl-1. Molecular Endocrinology 5 1633-1641.

Drucker DJ, Jin T, Asa S, Young T \& Brubaker PL 1994 Activation of proglucagon gene transcription by protein kinase-A in a novel mouse enteroendocrine cell line. Molecular Endocrinology 8 1646-1655.

Gazdar AF, Chick WL, Oie HK, Sims HL, King DL, Weir GC \& Lauris V 1980 Continuous, clonal, insulin- and somatostatin-secreting cell lines established from a transplantable rat islet cell tumor. PNAS 77 3519-3523.

German MS, Wang J, Chadwick RB \& Rutter WJ 1992 Synergistic activation of the insulin gene by a LIM-homeo domain protein and a basic helix-loop-helix protein: building a functional insulin minienhancer complex. Genes and Development 6 2165-2176.

Graef IA \& Crabtree GR 1997 The transcriptional paradox: octamer factors and B and T cells. Science 277 221-225.

Graham LD 2002 Ecdysone-controlled expression of transgenes. Expert Opinion on Biological Therapy 2 525-535.

Hussain MA \& Habener JF 1999 Glucagon gene transcription activation mediated by synergistic interactions of pax- 6 and $c d x-2$ with the p300 co-activator. Journal of Biological Chemistry 274 28950-28957.

Hussain MA, Miller CP \& Habener JF 2002 Brn-4 transcription factor expression targeted to the early developing mouse pancreas induces ectopic glucagon gene expression in insulin-producing beta cells. Journal of Biological Chemistry 277 16028-16032.

Ingraham HA, Chen RP, Mangalam HJ, Elsholtz HP, Flynn SE, Lin CR, Simmons DM, Swanson L \& Rosenfeld MG 1988 A tissue-specific transcription factor containing a homeodomain specifies a pituitary phenotype. Cell $\mathbf{5 5}$ 519-529.

James R \& Kazenwadel J 1991 Homeobox gene expression in the intestinal epithelium of adult mice. Journal of Biological Chemistry 266 3246-3251.

James R, Erler T \& Kazenwadel J 1994 Structure of the murine homeobox gene $\mathrm{Cdx}-2$ : expression in embryonic and adult intestinal epithelium. Journal of Biological Chemistry 266 15229-15237.

Jin T \& Drucker DJ 1995 The proglucagon gene upstream enhancer (GUE) contains positive and negative domains important for tissue-specific proglucagon gene transcription. Molecular Endocrinology 9 1306-1320.

Jin T \& Drucker DJ 1996 Activation of proglucagon gene transcription through a novel promoter element by the caudal-related homeodomain protein $\mathrm{cdx}-2 / 3$. Molecular and Cellular Biology 16 19-28.

Jin T, Trinh DK, Wang F \& Drucker DJ 1997 The caudal homeobox protein $\mathrm{cdx}-2 / 3$ activates endogenous proglucagon gene expression in InR1-G9 islet cells. Molecular Endocrinology 11 203-209.

Jin T, Branch DR, Zhang X, Qi S, Youngson B \& Goss PE 1999 POU homeobox gene expression in human breast cancer cells. International Journal of Cancer 81 104-112.

Jin T \& Li H 2001 POU homeodomain protein OCT1 is implicated in the expression of the caudal-related homeobox gene Cdx-2. Journal of Biological Chemistry 276 14752-14758.

Karlsson O, Thor S, Norberg T, Ohlsson H \& Edlund T 1990 Insulin gene enhancer binding protein Isl-1 is a member of a novel class of proteins containing both a homeo- and a Cys-His domain. Nature 344 879-882.

Laser B, Meda P, Constant I \& Philippe J 1996 The caudal-related homeodomain protein $\mathrm{Cdx}-2 / 3$ regulates glucagon gene expression in islet cells. Journal of Biological Chemistry 271 28984-28994. 
Leonard J, Peers B, Johnson T, Ferreri K, Lee S \& Montminy MR 1993 Characterization of somatostatin transactivating factor-1, a novel homeobox factor that stimulates somatostatin expression in pancreatic islet cells. Molecular Endocrinology 7 1275-1283.

Lu M, Miller C \& Habener JF 1996 Functional regions of the homeodomain protein IDX-1 required for transactivation of the rat somatostatin gene. Endocrinology 137 2959-2967.

McKinnon CM \& Docherty K 2001 Pancreatic duodenal homeobox-1, PDX-1, a major regulator of beta cell identity and function. Diabetologia 44 1203-1214.

Melloul D 2004 Transcription factors in islet development and physiology: role of PDX-1 in beta-cell function. Annals of the New York Academy of Sciences 1014 28-37.

Melloul D, Marshak S \& Cerasi E 2002 Regulation of pdx-1 gene expression. Diabetes 51 S320-S305.

Miller CP, McGehee RE Jr, Habener JF 1994 IDX-1: a new homeodomain transcription factor expressed in rat pancreatic islets and duodenum that transactivates the somatostatin gene. EMBO Journal 13 1145-1156.

Ohlsson H, Karlsson K \& Edlund T 1993 IPF1, a homeodomaincontaining transactivator of the insulin gene. EMBO Journal 12 4251-4259.

Patrick CW Jr, Zheng B, Wu X, Gurtner G, Barlow M, Koutz C, Chang D, Schmidt M \& Evans GR 2001 Muristerone A-induced nerve growth factor release from genetically engineered human dermal fibroblasts for peripheral nerve tissue engineering. Tissue Engineering 7 303-311.

Philippe J, Chick WL \& Habener JF 1987 Multipotential phenotypic expression of genes encoding peptide hormones in rat insulinoma cell lines. Journal of Clinical Investigation 79 351-358.

Poitout V, Olson LK \& Robertson RP 1996 Insulin-secreting cell lines: classification, characteristics and potential applications. Diabetes Metabolism 22 7-14.

Ritz-Laser B, Gauthier BR, Estreicher A, Mamin A, Brun T, Ris F, Salmon P, Halban PA, Trono D \& Philippe J 2003 Ectopic expression of the beta-cell specific transcription factor Pdx1 inhibits glucagon gene transcription. Diabetologia 46 810-821.
Sander M \& German MS 1997 The beta cell transcription factors and development of the pancreas. Journal of Molecular Medicine $\mathbf{7 5}$ 327-340.

Sander M, Neubuser A, Kalamaras J, Ee HC, Martin GR \& German MS 1997 Genetic analysis reveals that PAX6 is required for normal transcription of pancreatic hormone genes and islet development. Genes and Development 11 1662-1673.

Schreiber E, Matthias P, Muller MM \& Schaffner W 1989 Rapid detection of octamer binding proteins with 'mini-extracts', prepared from a small number of cells. Nucleic Acids Research 176419.

St-Onge L, Sosa-Pineda B, Chowdhury K, Mansouri A \& Gruss P 1997 Pax6 is required for differentiation of glucagon-producing alpha-cells in mouse pancreas. Nature 387 406-409.

Suh E, Chen L, Taylor J \& Traber PG 1994 A homeodomain protein related to caudal regulates intestine-specific gene transcription. Molecular and Cellular Biology 14 7340-7351.

Tucker JD, Dhanvantari S \& Brubaker PL 1996 Proglucagon processing in islet and intestinal cell lines. Regulatory Peptides $\mathbf{6 2}$ 29-35.

Uesaka T, Kageyama N \& Watanabe H 2004 Identifying target genes regulated downstream of $\mathrm{Cdx} 2$ by microarray analysis. Journal of Molecular Biology 337 647-660.

Wang P, Branch DR, Li H, Huiqin Li, Bali M, Schultz GA, Goss PE \& Jin T 2003 The POU homeodomain protein OCT3 as a potential transcriptional activator for fibroblast growth factor 4 in human breast cancer cells. Biochemical Journal $\mathbf{3 7 5}$ 199-205.

Wang Q \& Brubaker PL 2002 Glucagon-like peptide-1 treatment delays the onset of diabetes in 8 week-old $\mathrm{db} / \mathrm{db}$ mice. Diabetologia 45 1263-1273.

Xu F, Li H \& Jin T 1999 Cell type specific auto-regulation of the caudal-related homeobox gene Cdx-2/3. Journal of Biological Chemistry 274 34310-34316.

Received in final form 5 April 2005

Accepted 14 April 2005 